\title{
PENERAPAN GERAKAN LITERASI SEKOLAH PADA PEMBELAJARAN BAHASAINDONESIA DI SD NEGERI COT LHEUE RHENG
}

\author{
Rohani \\ SD Negeri Cot Lheue Rheng \\ Rohani10@gmail.com
}

\begin{abstract}
The purpose of this study was to describe the implementation of the school literacy movement program in Cot Lheue Rheng Elementary School through Indonesian language lessons by utilizing the potential of local culture. This study uses descriptive qualitative. The data collection techniques are observation and interview. The results of this study can be described that of the 5 steps in the stage of habituation of the school literacy movement in Cot Lheue Rheng Elementary School, not all steps can be taken to the full. Second, the implementation of the school literacy movement is limited to activities in the classroom. Third, the Neighborhood does not fully support this school literacy Movement program so the Environment does not provide source text as a reading. Fourth, the selection of reading books only through textbooks and assessment of community involvement has not been carried out optimally to support the school literacy movement program.
\end{abstract}

Keywords: Implementation, GLS, culture, Indonesia language

\begin{abstract}
Abstrak
Tujuan penelitian ini adalah untuk mendeskripsikan pelaksanaan program gerakan literasi sekolah di SD Negeri Cot Lheue Rheng melalui pelajaran bahasa indonesia dengan pemanfaatan potensi budaya lokal. Penelitian ini menggunakan pendekatan kualitatif deskriptif. Adapun teknik pengumpulan data yaitu observasi dan wawancara. Hasil penelitian ini dapat dideskripsikan bahwasanya dari 5 langkah pada tahapan pembiasaan gerakan literasi sekolah di SD Negeri Cot Lheue Rheng, belum semua langkah-langkah dapat dilakukan secara maximal yakni sekolah belum melakukan pembiasaan pada siswa untuk membaca 15 menit sebelum pelajaran dimulai, tetapi hanya 5 menit. Kedua, pelaksanaan gerakan literasi sekolah hanya terbatas pada kegiatan di dalam kelas. Ketiga, lingkungan sekitar belum mendukung sepenuhnya adanya program gerakan literasi sekolah ini sehingga lingkungan tidak menyediakan aneka teks sebagai sumber bacaan. Keempat, pemilihan buku bacaan hanya melalui buku teks pelajaran dan kelima pelibatan publik belum dilakukan secara maksimal untuk mendukung adanya program gerakan literasi sekolah.
\end{abstract}

Kata Kunci:Penerapan, GLS, budaya, Bahasa Indonesia

\section{Pendahuluan}

Rendahnya budaya literasi di Indonesia membuat pendidikan di Indonesia tertinggal dari negera-negara tetangga. Kondisi ini terjadi, menurut penelitian tersebut, disebabkan guru yang lebih banyak melaksanakan pembelajaran tentang bahasa dibanding dengan pembelajaran berbahasa.
Meskipun demikian, tantangan yang dihadapai pada saat ini adalah rendahnya minat baca. Banyak faktor mengapa anak atau siswa memiliki minat baca yang rendah seperti halnya ketersediaan buku bacaan yang masih terbatas. Secara psikologis, rendahnya motivasi siswa untuk menggali pengetahuan dari sumber bacaan juga sangat 
rendah. Rendahnya minat dan motivasi membaca sebagian berakar dari masih kuatnya tradisi lisan dalam kehidupan sosial dan pola berpikir masyarakat Indonesia. kondisi ini sangat memprihatinkan, terlebih lagi pada era global ini, siswa dituntut untuk memiliki kemampuan membaca dalam pengertian memahami teks secara analitis, kritis dan reflektif.

Membaca merupakan jendela dunia untuk dapat mengetahui ilmu dan pengetahuan. Selain dapat mengetahui perkembangan ilmu dan pengetahuan, dengan membaca, siswa dapat memahami esensi dari ilmu pengetahuan. Kemampuan memahami dalam setiap bacaan, sangat berkaitan erat dengan keterampilan siswa dalam membaca. Kegiatan membaca harus menjadi budaya pembiasaan yang harus ditanamkan dalam kegiatan pembelajaran di kelas karena membaca merupakan esensi tertua pada setiap muatan pelajaran. Potensi siswa harus diberdayakan dalam kegiatan pembelajaran di kelas agar penguasaan kompetensi siswa dapat tercapai sesuai harapan.

Pada era global ini, terdapat berbagai tantangan dalam mendorong dan memotivasi siswa untuk membaca. Misalnya saja dengan adanya teknologi yang menyediakan berbagai model dan kemudahan untuk memperoleh informasi, terkadang dijadikan jalan pintas untuk menghindari bacaan berupa buku cetak. siswa kurang teratrik dengan buku bacaan atau buku cetak yang telah disediakan. Padahal dengan membaca, dapat melatih siswa dalam berpikir kritis, memahami informasi yang terkadung dalam bacaan.

Peralihan tradisi dari metode membaca buku teks ke metode membaca di media teknologi, memberikan dampak terhadap budaya literasi. Hal ini yang harus menjadi perhatian guru bagaimana menciptakan buadaya literasi di sekolah. Tentu membutuhkan berbagai upaya dan usaha serta pendekatan dalam metode atau model pembelajaran. Menurut data Kemdikbud (2016:1) menjelaskan bahawasanya PISA 2009, peserta didik Indonesia berada pada peringkat ke-57 dengan skor 396 (skor ratarata OECD 493), sedangkan PISA 2012 menunjukkan peserta didik Indonesia berada pada peringkat ke-64 dengan skor 396 (skor rata-rata OECD 496). Sebanyak 65 negara berpartisipasi dalam PISA 2009 dan 2012. Oleh karena itu diperlukan upaya dan strategi agar peringkat Indonesia ada peningkatan dari setiap tahunnya.

Semua pihak dalam pendidikan baik dari lingkup keluarga, lingkungan, guru atau pemerintah harus memiliki komitmen dalam mengupayakan peningkatan mutu pendidikan. Untuk mewujudkan proses dan hasil pembelajaran yang bermutu harus dilakukan secara terus menerus dan berkelanjutan. Seperti halnya pada pembelajaran Bahasa Indonesia, dimana upaya meningkatkan mutu pembelajaran bahasa Indonesia bukanlah persoalan yang mudah karena pembelajaran merupakan sistem yang kompleks. Terdapat empat faktor utama dalam pembelajaran, yaitu sekolah, guru, proses pembelajaran, dan siswa. Pendekatan sistemik dan sistematik sangat diperlukan untuk mengatasi berbagai persoalan yang ada karena persoalan dalam pendidikan sangatlah kompleks. Perbaikan pada berbagai komponen pendidikan harus dilakukan secara terus menerus dan mampu menjangkau semua aspek dimensi baik secara teoritis, konseptual, regulasi maupun dimensi praktis. Oleh karena itu, diperlukan sinergi oleh seluruh seluruh pemangku kepentingan pendidikan mulai dari unsur guru, kepala sekolah, dosen, pengawas, pengarang,penulis buku, pengembang model pembelajaran, pengembang model penilaian, pengembang kurikulum, Lembaga, sekolah, perguruan tinggi, pemerintah, dan masyarakat sangatlah diperlukan.

Berdasarkan hal tersebut, Pemerintah mendorong semua elemen agar kegiatan Literasi dapat digalakkan. Oleh karena itu pemerinah pada tahun 2015 menerapkan Gerakan Literasi Sekolah (GLS) dimana salah satu wujud gerakan membaca ini dituangkan dalam Peraturan Menteri Pendidikan dan Kebudayaan Nomor 23 Tahun 2015 tentang Penumbuhan Budi 
Pekerti, yang salah satu kegiatannya adalah membaca buku non pelajaran selama 15 menit sebelum waktu belajar dimulai. Gerakan Literasi Sekolah diharapkan dapat menumbuhkan minat baca peserta didik dan meningkatkan keterampilan membaca agar pengetahuan dapat dikuasai secara lebih baik. Materi baca berisi nilai-nilai budi pekerti, berupa kearifan lokal, nasional, dan global yang disampaikan sesuai tahap perkembangan peserta didik. Tentunya hal itu butuh arahan dari seorang guru yang menjadi fasilitator dalam kelas untuk mendampingi siswa dalam membaca.

Budaya membaca harus menjadi kebiasaan yang dilakukan siswa, baik siswa yang berada di kota, di desa, di kepulauan ataupun siswa yang berada diperbatasan wilayah. Seperti halnya siswa di SD Negeri Cot Lheue Rheng Gampong Cot Lheue Rheng merupakan daerah pedesaan yang masuk ke dalam administrasi kabupaten Pidie Jaya, dimana secara geografis, budaya, dan sosiologi gampong Cot Lheue Rheng masih sangat terikat dengan budaya kedaerahan salah satu nya segi bahasa. Mayoritas masyarakat Cot Lheue Rheng masih mengunakan bahasa daerah sebagai bahasa bahasa komunikasi sesama dalam kehidupan bermasyarakat, tentunya budaya ini bisa dikaji sebagai penunjang dalam pembelajaran bahasa Indonesia khususnya dalam meningkatkan budaya membaca melalui pemanfaatan budaya Daerah perbatasan Sumenep dan Pamekasan. Misalnya di Sekolah Dasar Negeri Kaduara Timur yang lokasi sekolahnya berada pada daerah perbatasan antara Sumenep dan Pamekasan.

Pengertian Literasi Sekolah dalam konteks GLS adalah kemampuan

mengakses, memahami, dan menggunakan sesuatu secara cerdas melalui berbagai aktivitas, antara lain membaca, melihat, menyimak, menulis, dan/ atau berbicara. GLS merupakan sebuah upaya yang dilakukan secara menyeluruh untuk menjadikan sekolah sebagai organisasi pembelajaran yang warganya literat sepanjang hayat melalui pelibatan publik (Kemdikbud, 2016:2).

Tujuan Umum diterapkannya gerakan literasi sekolah adalah menumbuh kembangkan budi pekerti peserta didik melalui pembudayaan ekosistem literasi sekolah yang diwujudkan dalam Gerakan Literasi Sekolah agar mereka menjadi pembelajar sepanjang hayat. Sedangkan tujuan khusus gerakan literasi sekolah adalah

1. Menumbuh kembangkan budaya literasi di sekolah;

2. Meningkatkan kapasitas warga dan lingkungan sekolah agar literasi;

3. Menjadikan sekolah sebagai taman belajar yang menyenangkan dan ramah anak agar warga sekolah mampu mengelola pengetahuan;

Menjaga keberlanjutan pembelajaran dengan menghadirkan beragam buku bacaan dan mewadahi berbagai strategi membaca

Salah satu upaya penumbuhan budi pekerti yang merupakan tujuan mum GLS ini dapat dilakukan dengan cara membaca berbagai materi baca yang berisikan nilai-nilai moral dalam konteks kebangsaan dan kenegaraaan Indonesia seperti nilai-nilai budi pekerti, kearifan lokal, nasional, dan global yang disampaikan sesuai tahap perkembangan peserta didik. Kegiatan membaca tersebut dapat dilakukan 15 menit setiap hari pada saat pelajaran di kelas dimulai, atau disesuaikan dengan kondisi sekolah masingmasing. Hal ini merupakan salah satu dasar dalam tahap pembiasaan sebelum masuk ke tahap pengembangan dan pembelajaran.

Dalam pembelajaran bahasa Indonesia, khusunya pada kelas tinggi yaitu kelas 4-6 SD, kegiatan membaca merupakan kegiatan yang dilakukan untuk memahami dan berpikir yang terjadi bersamaan sehingga membaca pada kelas 4-6 SD terjadi kegiatan berpikir memahami suatu bacaan bukan hanya belajar mengeja huruf atau ucapan (Tarigan, 2008 :38). Pada tingkat sekolah dasar khusunya kelas tinggi, (Tarigan, 2008 :38) menyatakan bahwa 
kegiatan membaca pemahaman meliputi 3 hal yaitu pertama, membaca dengan pemahaman baik. Kedua, Membaca tanpa menunjuk, gerakan bibir dan kepala, dan ketiga, Membaca dalam hati.

\section{Menurut Muhyidin}

kemampuan membaca dan memahami teks pada siswa tingkat sekolah dasar merupakan hal yang pokok dan sangat mendasar khususnya dalam perkembangan di masa mendatang agar informasi yang ada dapat ditangkap, diserap dan diburu sehingga ketika mereka mencapai pendidikan yang lebih tinggi dapat berkembang menyesuaikan dengan perkembangan ilmu dan teknologi. Oleh karena itu, membaca menjadi kegiatan yang harus dibiasakan dan menjadi kebutuhan bagi siswa.

Gerakan literasi sekolah dalam kurikulum K13 edisi revisi 2017 sudah menjadi kewajiban yang harus dilakukan dalam pembelajaran baik dari tingkat sekolah dasar sampai dengan sekolah menengah atas. Tahapan pelaksanaan gerakan literasi sekolah terbagi menjadi 3 tahap yakni tahap pembiasaan, tahap pengembangan dan tahap pembelajaran. Berikut ini gambaran tentang tahapan pelaksanaan gerakan literasi sekolah yang dapat diterapkan di sekolah dasar adalah sebagai berikut:

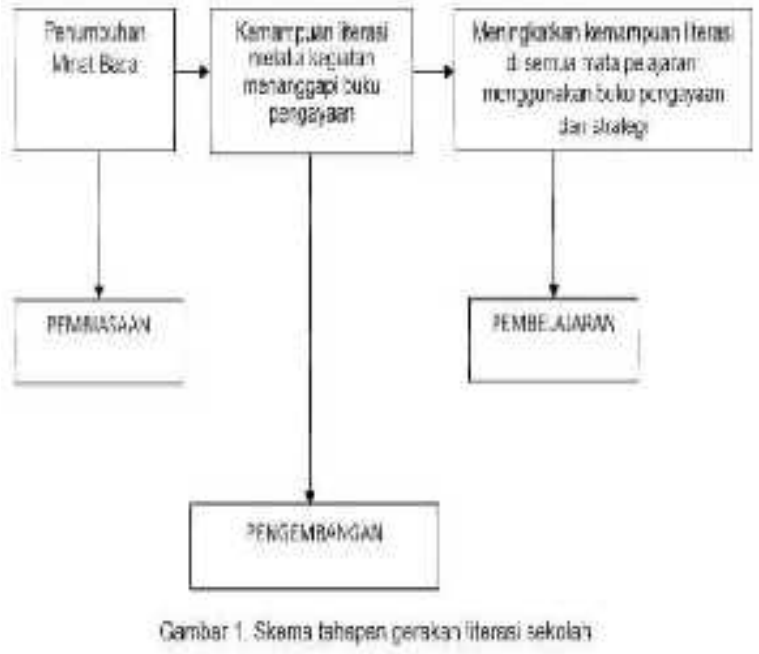

Dari skema tahapan di atas, dapat dijabarkan kembali masing-masing tahapan tentang konsep pelaksanaan gerakan literasi sekolah.

\begin{tabular}{|c|c|c|}
\hline Pexpbasain & Pencanbasgan & Penbégejuran \\
\hline 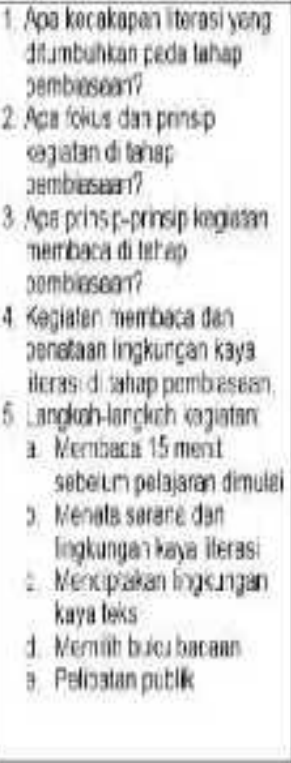 & 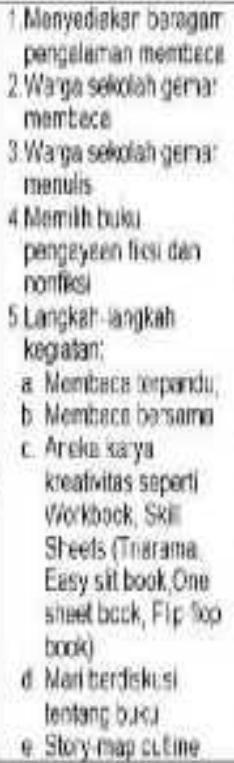 & 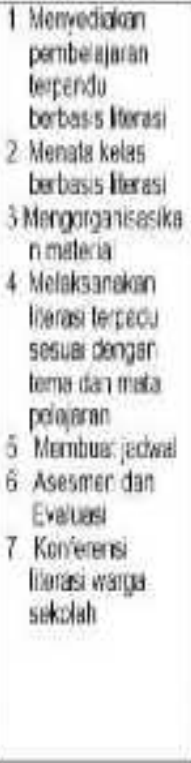 \\
\hline
\end{tabular}

Gerakan Literasi Sekolah (GLS) di SD dilaksanakan secara bertahap dengan mempertimbangkan kesiapan masingmasing sekolah. Kesiapan ini mencakup kesiapan kapasitas fisik sekolah (ketersediaan fasilitas, sarana, prasarana literasi), kesiapan warga sekolah (peserta didik, tenaga guru, orang tua, dan komponen masyarakat lain), dan kesiapan sistem pendukung lainnya (partisipasi publik, dukungan kelembagaan, dan perangkat kebijakan yang relevan).

Menurut Surangangga (dalam Batubara: 2018:16) pelaksanaan program gerakan literasi sekolah mengacu pada prinsip, pertama, sesuai dengan tahapan perkembangan peserta didik, kedua, dilaksanakan menggunakan berbagai ragam teks, Ketiga, dilaksanakan secara terintegrasi dan holistik di semua area kurikulum, keemepat, dilakukan secara berkelanjutan, Kelima, melibatkan kecakapan berkomunikasi lisan, dankeenam, mem pertimbangkan keberagaman. 
Dari tiga tahapan gerakan literasi sekolah (GLS), masing-masing tahapan memiliki indikator pencapaian. Dalam hal ini akan diuraikan indikator pencapaian pada tahapan pembiasaan.

\begin{tabular}{|c|c|}
\hline 10 & Inonater \\
\hline 7 & 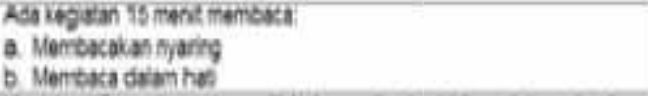 \\
\hline 2 & 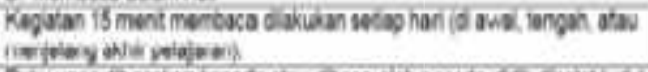 \\
\hline 3 & 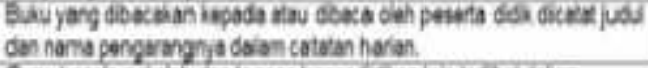 \\
\hline 4 & 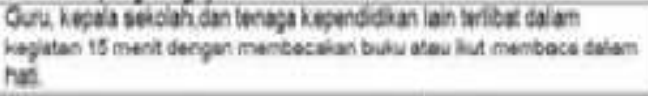 \\
\hline 5 & 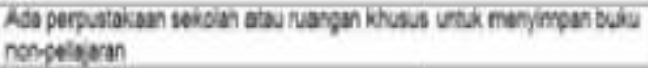 \\
\hline 8 & 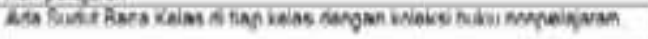 \\
\hline 7 & 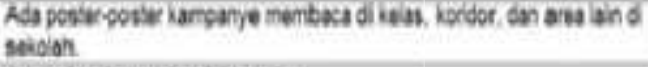 \\
\hline 8 & 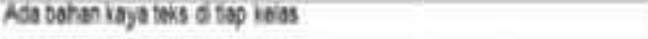 \\
\hline 9 & 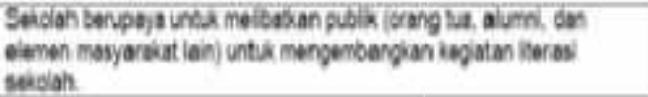 \\
\hline
\end{tabular}

\section{METODE PENELITIAN}

Penelitian ini menggunakan pendekatan kualitatif deskriptif yang bertujuanuntuk mengambarkan implementasi gerakan literasi sekolah pada pembelajaran bahasa Indonesia di SD Negeri Cot Lheue Rheng Kecamatan Meureudu kabupaten Pidie Jaya. Sumber data yang digunakan dalam penelitian ini adalah guru dan siswa kelas IV SD Negeri Cot Lheue Rheng Kecamatan Meureudu kabupaten Pidie Jaya. Teknik pengumpulan data dilakukan dengan wawancara, obrservasi dan dokumentasi. Teknik pengumpulan data dilakukan dengan wawancara kepada guru dan siswa serta tenaga perpustakaan untuk mengetahui informasi tentang penerapan gerakan literasi sekolah di SD Negeri Cot Lheue Rheng Kecamatan Meureudu kabupaten Pidie Jaya. Sedangkan observasi dilakukan pada siswa dan guru pada saat pembelajaran di kelas. Dokumentasi dilakukan untuk mendukung kegiatan penelitian yakni berupa data-data sekolah yang berkaitan dengan gerakan literasi sekolah. Instrumen yang digunakan dalam penelitian ini adalah pedoman wawancara dan observasi serta dokumentasi. Teknik Analisis data penelitian ini dilakukan dengan reduksi data, penyajian data dan penarikan kesimpulan (Sugiyono, 2010: 142)

\section{HASIL DAN PEMBAHASAN}

Pada pembahasan ini akan di deskripsikan kegiatan gerakan literasi sekolah khususnya pada pelajaran bahasa indonesia di SD Negeri Cot Lheue Rheng Kecamatan Meureudu kabupaten Pidie Jaya. Berdasarkan hasil observasi, dimana program GLS di sekolah ini masih berada pada tahapan pembiasaan. Oleh karena itu, Peneliti menggunakan tabel ceklis Indikator pencapaian pada tahap pembiasaan. Tabel ceklis ini digunakan untuk mengetahui apakah prioritas kegiatan di tahap pembiasaan literasi sudah dilaksanakan di sekolah. Adapun hasil observasi dengan menggunakan indikator pencapaian GLS pada tahap pembiasaan ini adalah sebagai berikut:

Tebel 3. Hasil Observasi Gerakan Literasi sekolah pada tahap pembiasaan

\begin{tabular}{|c|c|c|c|c|}
\hline No & Indikator & $\begin{array}{c}\text { Waktu } \\
\text { Pelaksanaan }\end{array}$ & sudah & belum \\
\hline 1 & $\begin{array}{l}\text { Ada Kegiatan } 15 \\
\text { menit membaca } \\
\text { a. Membaca } \\
\text { Nyaring } \\
\text { b.Membaca dalam } \\
\text { hati }\end{array}$ & Rabu Pagi & $\sqrt{ }$ & \\
\hline 2 & $\begin{array}{ll}\text { Membaca } & \text { Yasin } \\
\text { setiap pagi } & \text { Jumat } \\
\end{array}$ & & $\sqrt{ }$ & \\
\hline 2 & $\begin{array}{l}\text { Kegiatan15 Menit } \\
\text { Membaca dilaku } \\
\text { kan setiap } \\
\text { hari(diawal, } \\
\text { ditengah,atau } \\
\text { menjelang akhir } \\
\text { pelajaran) }\end{array}$ & & & $\checkmark$ \\
\hline 3 & $\begin{array}{l}\text { Buku yang dibaca } \\
\text { kan kepada atau } \\
\text { oleh peserta } \\
\text { dicatat judul atau } \\
\text { nama pengarang } \\
\text { nya dalam catatan } \\
\text { harian }\end{array}$ & & & $\checkmark$ \\
\hline 4 & $\begin{array}{lr}\text { Kepala } & \text { Sekolah, } \\
\text { guru } & \\
\text { dan tenaga kepend } \\
\text { idikan } & \text { terlibat } \\
\text { dalam kegiatan } 15 \\
\text { menit } \\
\text { dengan } & \text { membaca } \\
\text { buku } & \text { atau } \\
\text { membaca } & \text { dalam } \\
\text { hati } & \\
\end{array}$ & & $\sqrt{ }$ & \\
\hline 5 & \begin{tabular}{lr}
\multicolumn{2}{l}{ Ada perpustakaan } \\
sekolah & atau \\
ruangan & khusus \\
\end{tabular} & & & $\checkmark$ \\
\hline
\end{tabular}




\begin{tabular}{|l|l|l|l|l|}
\hline & $\begin{array}{l}\text { untuk menyimpan } \\
\text { buku non bacaan }\end{array}$ & & \\
\hline 6 & $\begin{array}{l}\text { Ada Poster } \\
\text { poster kampanye } \\
\text { membaca di kelas, } \\
\text { koridor dan area } \\
\text { lain di sekolah }\end{array}$ & & \\
\hline 7 & $\begin{array}{l}\text { Ada sudu baca } \\
\text { kelas di tiap kelas } \\
\text { dengan koleksi } \\
\text { buku non } \\
\text { pelajaran }\end{array}$ & & \\
\hline 8 & $\begin{array}{l}\text { Ada bahan kaya } \\
\text { teks di tiap kelas }\end{array}$ & & \\
\hline 9 & $\begin{array}{l}\text { Mempublikasi } \\
\text { hasil karya siswa } \\
\text { di majalah dinding }\end{array}$ & & & \\
\hline 10 & $\begin{array}{l}\text { Sekolah berupaya } \\
\text { untukmelibatkan } \\
\text { publik ( Orang } \\
\text { tua masyarakat, } \\
\text { Komite, alumni } \\
\text { dan elemen } \\
\text { masyarakat lain) } \\
\text { untuk } \\
\text { mengembangkan } \\
\text { kegiatan literasi } \\
\text { sekolah (GLS) }\end{array}$ & & & \\
\hline
\end{tabular}

Dari hasil penelitian, dapat dideskripsikan pelaksanakan program gerakan literasi sekolah di SD Negeri Cot Lheue Rheng Kecamatan Meureudu kabupaten Pidie Jaya adalah sebagai berikut:

1. Ada kegiatan 15 menit membaca: membaca dengan nyaring dan membaca dalam hati

Dalam langkah ini sekolah sudah menerapkan kegiatan membaca dengan nyaring dan juga kegiatan membaca dalam hati. Kegiatan membaca dengan nyaring dilakukan oleh siswa pada saat siswa ditunjuk oleh guru untuk membaca buku teks di depan kelas dan di depan temantemannya. Sementara siswa yang lain menyimak apa yang dibacakan oleh temannya. Kegiatan membaca dalam hati dilakukan pada saat siswa diberi teks dalam bentuk kelompok kerja diman teks diberikan pada maisng-masing individu. Artinya setiap siswa mendapatkan lembar yang berisi bacaan. Siswa membaca dalam hati untuk lebih fokus danmencermati isi dari teks bacaan tersebut.

2. Kegiatan Membaca 15 Menit Sebelum Pelajaran Dimulai

Pada langkah ini dapat dideskripsikan bahwasanya guru dalam memulai pembelajaran di awali dengan salam yang dilanjutkan dengan kegiatan berdoa dan mengecek kehadiran siswa, mengoreksi pekerjaan rumah siswa. Kemudian guru meminta siswa untuk membuka buku teks pelajaran kelas IV dan meminta siswa untuk membaca dalam hati. Secara serentak guru dan siswa membaca buku pelajaran yang yang memuat bacaan tentang tema indahnya kebersamaan.

Selanjutnya guru menunjuk beberapa orang siswa agar menceritakan kembali teks yang di bacanya di depan teman-temannya. Sementara siswa yang lain mendengarkan cerita teman yang di depan kelas. Setelah beberpa orang siswa menceritakan kembali apa yang di bacanya, selanjutnya meminta siswa yang lainnnya untuk bertanya tentang hal yang berkaitan dengan yang buku yang di baca. Sementara guru menaggapi pertanyaan dari siswa dan bersama sama dengan siswa melakuan diskusi tentang isi buku teks yang telah di baca oleh siswa.

Berdasarkan gambaran pembelajaran pada tahapan pendahuluan di atas, dapat dideskripsikan bahwasanya guru sudah melakukan kegaiatan membaca sebelum pelajaran dimulai, namun alokasi waktu yang diberikan pada tahapan pendahuluan belum menunjukkan waktu yang efektif, terkadang kurang dari 15 menit atau lebih. Selain itu sumber pemilihan buku yang digunakan hanya menggunakan buku teks dari buku siswa. Dalam hal ini siswa tidak diberikan buku teks bacaan dari sumber lainnya sebagai sumber referensi yang dapat menambah pengetahun siswa.

Kegiatan literasi sekolah dilakukan setiap hari namun hanya di awal pelajaran saja. Pada bagian tengah, dan akhir dari pelajaran, guru tidak melakukan kegiatan literasi tetapi fokus dalam melanjutkan kegiatan tema yakni melakukan penugasan dan penilaian.

3. Menata sarana dan lingkungan kaya literasi

Dari hasil observasi pada lingkungan sekolah, sekolah memiliki perpustakaan sekolah. Namun berdasarkan observasi dan wawancara pada saat penelitian, pemanfaatan perpustakaan dalam kegiatan 
belajar mengajar belum sepenuhnya digunakan dengan baik. Hal ini terlihat bahwasanya siswa terbatas pada buku teks yang dibacanya hanya buku pelajaran saja. Penggunaan sumber bacaan yang disediakan oleh sekolah tidak dimanfaatkan secara sepenuhnya oleh siswa.

Selain itu belum terlihat bahwasanya koleksi buku non pelajaran sabagai sumber literasi yang dapat dimanfaatkan oleh siswa terletak pada sudut kelas. Padahal pemanfaatan setiap pojok ruang kelas dapat dijadikan sebagai media untuk menyimpanan buku non pelajaran, sehingga siswa tidak hanya fokus membaca buku pelajaran saja tetapi buku-buku lain seperti cerita rakyat, dongeng serta cerita-cerita lain dapat diketahui oleh siswa dengan membaca.

4. Pembacaan Surah Yasin

Pada kegiatan ini setiap pagi jumat seluruh siswa berkumpul dihalaman sekolah dan secara bersama sama membaca surat yasin.

Berdasarkan gambaran diatas dapat di deskripsikan bahwa siswa sudah melaksanakan kegiatan literasi segmen keagamaan untuk membentuk akhlak, penguatan bidang keagamaan dan ini selaras dengan arah dan kebijakan dinas pendidikan Pidie Jaya dalam upaya membentuk karakter siswa

5. Menciptakan lingkungan kaya teks

Berdasarkan hasil pengamatan dan wawancara dengan kepala sekolah, diperoleh data atau informasi bahwasanya sekoah telah mengupayakan membuat sumber-sumber bacaan di lingkungan sekolah. Selain itu peneliti juga belum menjumpai adanya poster-poster yang mengkampanyekan tentang ajakan membaca bagi siswa, misalnya saja pada mading sekolah, papan pengumuman ataupun di tempat-tempat lainnya. Hal lain yang dapat dilakukan dengan memajang poster-poster atau gambar gambar yang di dalamnya memuat teks-teks sehingga mampu merangsang siswa dalam membaca buku tidak hanya pada saat kegiatan di kelas tetapi pada saat istirahat pun siswa dapat membaca buku-buku cerita khususnya buku cerita rakyat yang mengangkat tentang budaya lokal. Selain di mading dan papan pengumuman, sumber literasi juga dapat disediakan di kantin sekolah dengan menggunakan metode jual beli, gerakan literasi juga dapat diterapakan oleh siswa

Peneliti juga belum melihat posterposter yang dipajang pada kebun sekolah, kantin, dan UKS sehingga tidak hanya di dalam kelas tetapi lingkungan disekitar kelas juga mengandung dan kaya budaya literasi. Misalnya saja poster yang dapat dipajang di UKS adalah poster poster tentang pembiasaan hidup sehat, dilarang merokok. Poster yang dapat dipajang di area taman atau kebun sekolah adalah poster yang mengajak akan menjaga kebersihan, dan keindahan di kebun sekolah. Di area kantin juga dapat dimanfaatkan sebagai sarana yang mendukung budaya literasi. Misalnya saja gambar yang menyerukan bahwasanya makanan di kantin sekolah diolah dengan bersih dan sehat. Hal hal kecil seperti yang dikemukakan di atas dapat diterapkan dan dilakukan di lingkungan sekolah sebagai bagian dari pembiasaan siswa dalam membaca. Siswa secara tidak langsung akan membatu siswa menuju tahap pembiasaan membaca slogan, poster, gambar yang memuat teks dan ajakan tentang sesuatu yang baik. Pembiasaan-pembiasaan seperti ini perlu waktu untuk melatih siswa agar setiap saat siswa melakukan gerakan literasi sekolah.

6. Memilih Buku Bacaan di SD

Sumber bacaan yang disediakan dan diberikan pada siswa harus melalui proses seleksi baik dari pengelola perpustakaan ataupun dari guru. Hal ini untuk mengurangi adanya buku teks yang tidak seharusnya dibaca. Tentunya buku yang dipilih adalah buku yang sesuai dengan karakteristik siswa pada tingkat dasar.

Berdasarkan hasil wawancara dengan guru dan kepala sekolah didapatkan informasi bahwasanya buku-buku yang disediakan oleh sekolah sebagian besar 
adalah buku pelajaran umum. Hal ini yang terkadang membuat siswa agak malas untuk keperpustakaan. Seharusnya buku yang disediakan oleh pihak sekolah tidak hanya buku yang berhubungan dengan pelajaran tetapi perlu disediakan buku-buku lain sebagai penunjang pengetahuan siswa di bidang lainnya. Misalnya saja buku cerita rakyat, buku dongeng, buku pengetahuan tentang sejarah suatu daerah dan lain sebagainya.

7. Pelibatan Publik

\section{Berdasarkan wawancara dengan}

kepala sekolah, pada pelibatan publik untuk kegiatan gerakan literasi sekolah belum di lakukan secara khusus. Selama ini pertemuan yang dilakukan dengan wali hanya pada saat akan masuk sekolah dan pada saat menjelang akan keluar dari sekolah. Artinya dukungan sepenuhnya dari pihak wali murid belum pada kegiatan GLS. Oleh karena itu dalam jangka waktu ke depan pihak sekolah harus mampu merangkul semua aspek dalam mensukseskan gerakan literasi sekolah khususnya pada tahap pembiasaan ini. Selain itu sekolah sebaiknya perlu membentuk tim literasi untuk meningkatkan minat baca siswa.

\section{SIMPULAN}

Berdasarkan uraian hasil pembahasan di atas maka diperoleh kesimpulan sebagai berikut.

1. Pelaksanaan program gerakan literasi sekolah di SD Negeri Cot Lheue Rheng Kecamatan Meureudu kabupaten Pidie Jaya berada pada tahap pembiasaan;

2. Upaya upaya yang akan dilakukan oleh Pihaksekolahdalam mengimplementasikangerakan literasi sekolah adalah dengan menyediakan buku-buku referensi, buku cerita dan dongeng di perpustakaan, membuat sumber literasi diberbagai tempat seperti di mading, papan pengumuman dan tempat tempat strategis yang dapat dilihat oleh siswa.

\section{DAFTAR PUSTAKA}

Batubara, Hamdan Husein, Dessy Noor Ariani. Implementasi Program Gerakan Literasi Sekolah Di Sekolah Dasar Negeri Gugus Sungai Miai Banjarmasin. Jurnal JPSD Vol. 4 No. 1, Maret 2018 ISSN 2540-9093 EISSN 2503-0558

Depdiknas. 2006. Peraturan Menteri Pendidikan Nasional Republik Indonesia, Nomor 23 tahun 2006, tentang Standar Kompetensi Lulusan untuk Satuan Pendidikan Dasar dan Menengah. Jakarta: Depdiknas

Kemdikbud. 2016. Panduan Gerakan Literasi Sekolah di Sekolah Dasar. Jakarta.

Muhyidin, Asep. Dkk. 2018. Metode Pembelajaran membaca dan menulis permulaan di kelas awal. Jurnal JPSD vol 4 No 1. ISSN 2540-9093 \& E-ISSN 2503-0558. Hal 30-42

Permendikbud. 2016. Standar Isi Pendidikan Dasar dan Menengah. Jakarta

Rahim, Farida. 2011. Pengajaran Membaca di Sekolah Dasar. Jakarta: Bumi Aksara

Resmini, Novi dkk. 2006 Pembinaan dan Pengembangan Pembelajaran Bahasa. UPI Press

Sugiyono, 2010. Metode Penelitian Pendidikan pendekatan Kuantitatif, Kualitatif, dan R\&D. Bandung. Alfabeta

Tarigan, Henry Guntur. 2008. Membaca: sebagai suatuketerampilan berbahasa.Bandung: Angkasa 